\title{
PENGEMBANGAN MANAJEMEN PEMBELAJARAN AGAMA ISLAM
}

\author{
Zaenuri \\ Sekolah Tinggi Ilmu Tarbiyah (STIT) Ad-Dakwah Lebak Banten \\ zaenuri.stitadawah@gmail.com
}

\begin{abstract}
The success of Islamic Religious Education teachers in implementing learning is largely determined by their ability to implement management functions properly. The management of Islamic learning is a unit of teaching and learning process carried out by the teacher, starting from the planning, the process of activities, to the evaluation and follow-up process that takes place in learning to achieve the objectives of Islamic religious education. The inability of teachers to internalize management values in the learning process of Islamic Religion can be one of the factors causing the output of students who are unable to carry out the mission of national education, which is to be a human being who believes and is devoted to Allah SWT. Therefore, improvement of the management of Islamic learning must be carried out in order to realize an effective learning and achieve the expected goals.
\end{abstract}

Keywords: Management, Learning, Islamic Education.

\begin{abstract}
Abstrak
Keberhasilan guru Pendidikan Agama Islam dalam pelaksanaan pembelajaran sangat ditentukan oleh kemampuannya untuk mengimplementasikan fungsi-fungsi manajemen secara baik. Manajemen pembelajaran Agama Islam merupakan kesatuan proses belajar mengajar yang dilakukan oleh guru, mulai dari perencanaan, proses kegiatan, sampai dengan evaluasi serta proses tindak lanjut yang berlangsung dalam pembelajaran untuk tercapainya tujuan pendidikan
\end{abstract}


agama Islam. Ketidakmampuan guru untuk menginternalisasikan nilainilai manajemen dalam proses pembelajaran Agama Islam dapat menjadi salah satu faktor penyebab adanya output peserta didik yang tidak mampu mengemban misi pendidikan nasional, yaitu menjadi manusia yang beriman dan bertakwa kepada Allah SWT. Oleh karenanya, pembenahan terhadap manajemen pembelajaran agama Islam harus dilakukan untuk terwujudnya pembejaran yang efektif serta tercapainya tujuan yang diharapkan.

Kata Kunci: Manajemen, Pembelajaran, Pendidikan Agama Islam.

\section{A. PENDAHULUAN}

Proses pendidikan merupakan proses yang kontinyu, bermula sejak seseorang dilahirkan hingga meninggal dunia. Rumusan lainnya menyebutkan bahwa pendidikan tersebut mencakup bentuk-bentuk belajar secara formal maupun informal, baik yang berlangsung dalam lingkungan kerja, kehidupan sekolah, pekerjaan maupun kehidupan masyarakat. Pendidikan pada dasarnya adalah suatu proses memanusiakan manusia sejak masa kejadiannya sampai akhir hayatnya melalui berbagai ilmu pengetahuan yang yang disampaikan dalam bentuk pengajaran secara bertahap, dimana proses pengajaran itu menjadi tanggungjawab orangtua dan masyarakat menuju pendekatan diri kepada Allah SWT. ${ }^{1}$

Pendidikan Agama Islam sebagai disiplin ilmu yang merupakan konsep pendidikan yang mengandung berbagai teori yang dapat dikembangkan dari hipotesa-hipotesa yang bersumber dari alQuran maupun hadits baik dari segi sistem, proses dan produk yang diharapkan mampu membudayakan umat manusia agar bahagia dan sejahtera dalam hidupnya. Dari segi teori, pendidikan Islam dapat diartikan sebagai studi tentang proses kependidikan yang bersifat progresif menuju ke arah kemampuan optimal peserta didik yang berlangsung berlandaskan nilai-nilai ajaran agama Islam. Jadi,

1 Abidin Ibnu Rusn, Pemikiran Al-Ghazali Tentang Pendidikan, (Yogyakarta: Pustaka Pelajar, 1998), hlm. 54-56. 
pendidikan Islam yaitu sebuah proses yang dilakukan untuk menciptakan manusia-manusia yang seutuhnya (insan kamil). ${ }^{2}$

Dalam mencapai tujuan pendidikan tersebut dibutuhkan seorang pendidik yang mampu mengarahkan peserta didik dalam proses pembelajarannya menjadi generasi yang kita harapkan sesuai dengan tujuan pendidikan dan cita-cita bangsa. Karena itu maka seorang pendidik harus lebih banyak belajar dan berlatih untuk mengoptimalkan dirinya dalam proses belajar mengajar di kelas atau lebih luas lagi di lingkungan sekolah dengan memenej dan memaksimalkan segala potensi yang tersedia di lingkungan sekolah untuk mencapai tujuan pembelajaran agama Islam.

\section{B. Metode}

Penelitian ini merupakan jenis riset kepustakaan (library research), atau sering juga disebut studi pustaka atau penelitian kepustakaan, yaitu jenis penelitian yang dilakukan dengan membaca buku-buku atau majalah dan sumber data lainnya untuk menghimpun data dari berbagai literatur, baik perpustakaan maupun di tempat-tempat lain. ${ }^{3}$ Pengumpulan data dalam penelitian dilakukan dengan menelaah dan/atau mengekplorasi beberapa Jurnal, buku, dan dokumen-dokumen (baik yang berbentuk cetak maupun elektronik) serta sumber-sumber data dan atau informasi lainnya yang dianggap relevan dengan penelitian atau kajian.

\section{Pembahasan}

\section{Pengertian Pengembangan}

Secara etimologis kata pengembangan menurut Kamus Besar Bahasa Indonesia, berasal dari kata dasar "kembang/berkembang" yang artinya mekar terbuka, membentang atau membesar. Dengan mendapat awalan - pe dan akhiran - an, maka menjadi pengembangan yang berarti hal mengembangkan; pembangunan secara bertahap dan teratur, dan

2 Syuaib Kurdi dan Abdul Aziz, Model Pembelajaran Efektif PAI di SD dan MI, (Bandung: Pustaka Bani Quraisy, 2006), hlm. 6-8.

3Mahmud, Metode Penelitian Pendidikan, (Pustaka Setia: Bandung, 2011), hlm. 31 . 
yang menjurus ke sasaran yang dikehendaki. ${ }^{4}$ Sebagai contoh penggunaan kata pengembangan yaitu pada pengembangan bahasa, yaitu upaya meningkatkan mutu bahasa agar dapat dipakai untuk berbagai keperluan dl kehidupan masyarakat modern; atau pengembangan masyarakat, yaitu proses kegiatan bersama yang dilakukan oleh penghuni suatu daerah untuk memenuhi kebutuhannya. ${ }^{5}$

Dalam penelitian ini, penyusun memiliki kecenderungan untuk memilih definisi pengembangan sebagai suatu upaya untuk menigkatkan mutu pembelajaran agama Islam. Segala upaya yang akan dilakukan dalam upaya pengembangan pembelajaran untuk mendapatkan kemajuan dalam pendidikan.

\section{Pengertian Manajemen}

Manajemen sering diartikan sebagai ilmu, kiat, dan profesi. Dikatakan sebagai ilmu oleh Luther Gulick karena manajemen dipandang sebagai suatu bidang pengetahuan yang secara sistematik berusaha memahami mengapa dan bagaimana orang bekerjasama. Dikatakan sebagai kiat oleh Follet karena manajemen mencapai sasaran melalui cara-cara dengan mengatur orang lain dalam menjalankan tugas. Dipandang sebagai profesi karena manajemen dilandasi oleh keahlian khusus untuk mencapai suatu prestasi manajer, dan para profesional dituntun oleh suatu kode etik. ${ }^{6}$

Manajemen berasal dari Bahasa Inggris "to manage" yang berarti mengurus, mengatur, mengelola. ${ }^{7}$ Maka dalam penelitian ini kata "pengelolaan" memiliki makna yang sama dengan "management" dalam Bahasa Inggris, selanjutnya dalam Bahasa Indonesia menjadi "manajemen". ${ }^{8}$ Hal ini dapat kita pahami dari beberapa pengertian

4Tim Penyusun Kamus Pusat Bahasa, Kamus Bahasa Indonesia, (Jakarta: Pusat Bahasa, 2008), hlm. 679. (pdf.).

5http://ebsoft.web.id, Software KBBI v1.2, pada kata "Kembang".

6Nanang Fattah, Landasan Manajemen Pendidikan, (Bandung: Remaja Rosdakarya, 2004), hlm.1.

7U. Saefulloh, Manajemen Pendidikan Islam, (Bandung: Pustaka Setia, 2012), hlm. 1.

8 Martinis Yamin dan Maisah, Manajemen Pembelajaran Kelas: Strategi Meningkatkan Mutu Pembelajaran, (Jakarta: Gaung Persada Press, 2012, 1997), hlm. 34 . 
berikut. Menurut G. R. Terry manajemen merupakan proses khas yang terdiri atas tindakan-tindakan perencanaan, pengorganisasian, penggerakan dan pengendalian yang dilakukan untuk menentukan serta mencapai sasaran yang telah ditentukan melalui pemanfaatan SDM dan sumber daya lainnya. ${ }^{9}$ Manajemen merupakan proses pengordinasian dan pengintegrasian semua sumber, baik manusia, fasilitas, maupun sumber daya teknikal lainnya untuk mencapai berbagai tujuan yang telah ditetapkan. ${ }^{10}$ Pengelolaan adalah serangkaian kegiatan merencanakan, mengorganisasikan, memotivasi, mengendalikan, dan mengembangkan segala upaya dalam mengatur dan mendayagunakan SDM, sarana dan prasarana untuk mencapai tujuan organisasi. ${ }^{11}$ Pengelolaan (manajemen) adalah suatu upaya untuk mengatur (memenej, mengendalikan) aktivitas pengajaran berdasarkan konsepkonsep dan prinsip-prinsip untuk menyukseskan tujuan agar tercapai secara lebih efektif, efisien, dan produktif yang diawali dengan strategi dan perencanaan, diakhiri dengan penilaian. Dijelaskan selanjutnya bahwa pengelolaan menghasilkan sesuatu dan sesuatu itu dapat merupakan sumber penyempurnaan dan peningkatan pengelolaan selanjutnya. ${ }^{12}$

Dari uraian di atas dapat disimpulkan bahwa manajemen meliputi kegiatan merencana, mengoordinasi, memimpin dan mengendalikan berbagai sumber daya yang semuanya itu bersama-sama menghasilkan suatu hasil akhir yang memberikan informasi bagi penyempurnaan kegiatan, agar sesuatu yang dikelola, dalam hal ini adalah pembelajaran dapat berjalan dengan lancar, efektif dan efisien.

\section{Ibid, hlm. 3 .}

10 Sudarwan Danim dan Yunan Danim, Adminstrasi dan Manajemen Kelas, (Bandung: Pustaka Setia, 2010), hlm. 97.

11Afifuddin dan Sobri Sutikno. 2008. Pengelolaan Pendidikan: Teori dan Praktek. (Bandung: Prospect, 2008), hlm. 3.

12Ahmad Rohani, Pengelolaan Pengajaran: Sebuah Pengantar Menuju Guru Prfesional, (Jakarta: Rineka Cipta, 2010), hlm. 2. 
Dalam al-Quran hakikat manajemen adalah al-tadbir (pengaturan). Kata ini merupakan derivasi dari kata dabbara (mengatur), ${ }^{13}$ seperti dinyatakan dalam firman Allah SWT:

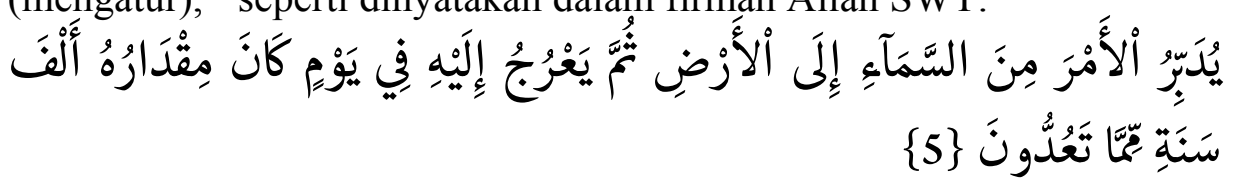

"Dia mengatur urusan dari langit ke bumi, kemudian (urusan) itu naik kepadaNya dalam satu hari yang kadarnya adalah seribu tahun menurut perhitunganmu".(QS. al-Sajdah [32]: 5) $)^{14}$

\section{Prinsip dan Fungsi-fungsi Manajemen \\ a. Prinsip Manajemen}

Dalam manajemen terdapat prinsip-prinsip yang merupakan pegangan umum pelaksanaan aktivitas manajerial, yang menentukan kesuksesan pengeoloaan organisasi. Henry Fayol mengetengah 14 prinsip manajemen yaitu:

1) Divisi kerja, objek divisi tugas adalah meningkatkan efisiensi melalui reduksi hal-hal yang tidak perlu, meningkatkan output, dan menyederhanakan pelatihan kerja.

2) Otoritas, otoritas yang baik untuk memberikan perintah melalui kekuasaan yang sangat dipatuhi, otoritas memberikan pertanggugjawaban dalam melaksanakan tugas dan kewajiban.

3) Disiplin, secara tidak langsung disiplin menyatakan kepatuhan terhadap peraturan organisasi. Kejelasan peryataan kesetujuan antara orgnisasi dan anggotanya sangat diperlukan, dan disiplin kelompok tergatung kualifikasi kepemimpinan.

4) Kesatuan komando, setiap anggota harus menerima perintah dari seorang atasannya ketaatan terhadap prinsip ini menghindarkan pembagian otoritas dan disiplin.

5) Kesatuan arah, kegiatan yang sama diarahkan untuk mencapai satu tujuan harus dikelompokkan bersama oleh seorang manajer.

13 U Saefullah, Manajemen, hlm. 1.

14 Departemen Agama RI, al-Quran dan Terjemahnya: al-'Aliy, (Bandung: CV. Diponegoro, 2000), hlm. 331. 
6) Subordinat minat individu, minat individu dan kelompok dalam sebuah organisasi tidak melebihi minat organisasi secara keseluruhan (mengutamakan kepentingan umum daripada individu).

7) Peggajian/kompensasi, kompensasi harus terbuka dan memuaskan anggota dan organisasinya.

8) Sentralisasi, manajer harus menguasai taggungjawab final, tetapi ia harus memberi bawahannya otoritas yang cukup untuk melaksanakan tugas dengan sukses. Kelayakan tingkat sentralisasi akan bervariasi tergantung suasana. Hal ini menjadi pertayaan bagaimana kelayakan sentralisasi yang dipakai dalam setiap kasus.

9) Rentang kendali, retang kendali atau rentang komando adalah rentang supervisor dari otoritas di atas ke bawahnnya. Garis otoritas harus jelas dan dipatuhi setiap waktu.

10) Perintah, manusia dan sumber daya material harus dikoordinasikan secara sesuai dan waktu yang tepat.

11) Pemerataan, kesamaan perlakuan yang diaspirasikan manajer terhadap seluruh bawahannya.

12) Stabilitas personel, kesuksesan oganisasi memerlukan kestabilan tempat kerja. Manajerial mempraktikkan keharusan komitmen jangka panjang anggota terhadap organisasinya.

13) Inisiatif, anggota harus didorong untuk mengembangkan dan melaksanakan rencana peningkatan.

14) Semangat tim, manajer harus mendukung dan memelihara kerja tim, semangat tim, dan rasa kebersamaan senasib dan seperjuangan anggotanya. ${ }^{15}$

Selain prinsip manajemen yang dikemukakan oleh Henry Fayol di atas, ada pula prinsip-prinsip manajemen yang pada dasarnya adalah sebagai berikut:

1) Prinsip efisiensi dan efektivitas, efisiensi dan efektivitas merupakan bagian dari prinsip-prinsip manajemen atau administrasi. Titik tolak pelaksanaan manajemen dalam organisasi semaksimal mungkin memanfaatkan semua sumber, tenaga, dana, dan fasilitas yang ada

15Martinis Yamin dan Maisah, Manajemen, hal. 30-31. 
secara efisien. Fungsi-fungsi manajemen dioprasionalisasikan dengan mempertimbangkan sarana dan prasarana yang seirama dengan keadaan dan kemampuan organisasi, artinya dengan menghemat biaya dan memperpendek waktu pelaksanaan kegiatan, tetapi hasil yang diperoleh tetap optimal.

2) Prinsip pengelolaan, manajer yang baik selalu bekerja dengan lagkah-lagkah manajemen yang fungsional, yaitu merencanakan, mengorganisasikan, menggerakan dan mengawasi. Dengan demikian target yang akan dituju dengan mudah dapat dicapai dengan baik.

3) Prinsip pengutamaan tugas pengelolaan, manajer adalah orang yang bertanggungjawab penuh dalam pelaksanaan organisasi dalam pelaksanaan organisasi, baik secara internal maupun eksternal. Internal artinya melaksanakan proses pengadministrasian semua aktivitas organisasi yang merupakan tugas utama manajer. Sedangkan ekternal adalah pelayanan manajerial terhadap semua kepentingan publik yang berkaitan dengan semua aktivitas manajemen di luar kelembagaan.

4) Prinsip kepemimpinan yang efektif, seorang pemimpin harus memliki kebijaksanaan dalam mengambil keputusan, artinya tegas, lugas, tuntas, dan berkualitas. Ia wajib mengembangkan hubungan baik dengan semua bawahannya, cerdas merealisasikan human relationship.

5) Prinsip kerjasama, prinsip kerjasama, didasarkan pada pengorganisasian dalam manajemen. Semua tugas dan kewajiban manajer tidak diborong oleh satu orang, tetapi dikerjakan menurut keahlian dan tugasnya masing-masing, sehingga beban kerjanya tidak menumpuk di satu tempat, sedangkan di tempat lain tidak ada yang harus dikerjakan. ${ }^{16}$

\section{b. Fungsi Manajemen dalam Pembelajaran}

Konsep-konsep manajemen di atas jika diterjemahkan dalam konsep pembelajaran dapat diartikan sebagai usaha dan tindakan kepala sekolah sebagai pemimpin instruksional di sekolah dan usaha maupun

16U. Saefullah, Manajemen, hal. 17-20. 
tindakan guru sebagai pemimpin pembelajaran di kelas dilaksanakan sedemikian rupa untuk mencapai hasil dalam rangka mencapai tujuan program sekolah dan juga pembelajaran. ${ }^{17}$

\section{1) Perencanaan}

Perencanaan dapat diartikan sebagai suatu cara yang memuaskan untuk membuat kegiatan dapat berjalan dengan baik, disertai dengan berbagai langkah yang antisipatif guna memperkecil kesenjangan yang terjadi sehingga kegiatan tersebut mencapai tujuan yang telah ditetapkan. ${ }^{18}$ Perencanaan pembelajaran pada prinsipnya meliputi: (1) menetapkan apa yang akan dilakukan oleh guru, kapan dan bagaimana cara melakukannya dalam implementasi pembelajaran; (2) membatasi sasaran atas dasar tujuan instruksional khusus dan menetapkan pelaksanaan kerja untuk mencapai hasil yang maksimal melalui proses penentuan target pembelajaran; (3) mengembangkan alternatif-alternatif yang sesuai dengan strategi pembelajaran; (4) mengumpulkan dan menganalisis informasi yang penting untuk mendukung kegiatan pembelajaran; dan (5) mempersiapkan dan mengkomunikasikan rencana-rencana dan keputusan-keputusan yang berkaitan dengan pembelajaran kepada pihak-pihak yang berkepentingan. ${ }^{19}$

Perencanaan pembelajaran penting dilakukan untuk memudahkan dilakunnya perbaikan pembelajaran. Upaya perbaikan pembelajaran ini dilakukan dengan asumsi sebagai berikut :

a) Untuk memperbaiki kualitas pembelajaran perlu diawali dengan perencanaan pembelajaran yang diwujudkan dengan adanya desain pembelajaran;

b) Untuk merancang suatu pembelajaran perlu menggunakan pendekatan sistem;

17Syaeful Sagala, Konsep dan Makna Pembelajaran, (Bandung: Al-Fabeta, 2012), hlm. 140.

18Hamzah B. Uno, Perencanaan Pembelajaran, (Jakarta: Bumi Aksara, 2011), hlm. 2.

19Syaiful Sagala, Konsep dan Makna, (Bandung : Alfabeta, 2012), hlm. 142. 
c) Perencanaan desain pembelajaran diacukan pada bagaimana seseorang belajar;

d) Untuk merencanakan suatu desain pembelajaran diacukan pada siswa secara perseorangan;

e) Pembelajaran yang dlakukan akan bermuara pada ketercapaian tujuan pembelajaran, baik tujuan langsung maupun tujuan pengiring dari pembelajaran;

f) Sasaran akhir dari perencanaan desain pembelajaran adalah mudahnya siswa dalam belajar;

g) Perencanaan pembelajaran harus melibatkan semua variabel pembelajaran;

h) Inti dari desain pembelajaran yang dibuat adalah penetapan metode pembelajaran yang optimal untuk mencapai tujuan yang telah ditetapkan.

Berkenaan dengan perencanaan, al-Quran mengisyaratkan bahwa konsep perencanaan hendaknya memerhatikan apa yang telah dikerjakan pada waktu sebelumnya untuk merencanakan sesuatu pada masa yang akan datang, ${ }^{20}$ sebagaimana firman Allah SWT:

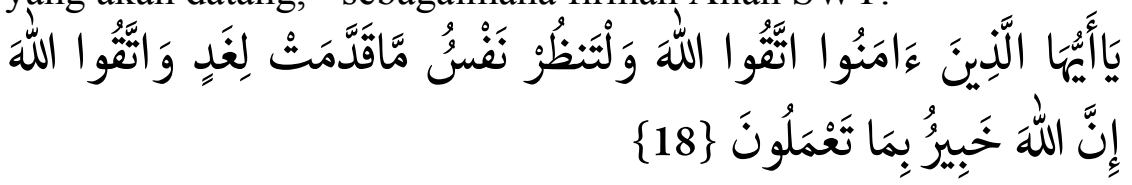

"Hai orang-orang yang beriman, bertakwalah kepada Allah dan hendaklah setiap diri memperhatikan apa yang telah diperbuatnya untuk hari esok (akhirat); dan bertakwalah kepada Allah, sesungguhnya Allah Maha Mengetahui apa yang kamu kerjakan".(QS. al-Hasyr [59]: 18) ${ }^{21}$

Terkait dengan perencanaan dalam dunia pendidikan, sahabat 'Ali pernah menyatakan: “Ajarilah anak-anak kalian (ilmu pengetahuan)

20 M. Munir dan Wahyu Ilaihi, Manajemen Dakwah, (Jakarta: Kencana, 2009), hlm. 98.

21 Departemen Agama RI, al-Quran dan Terjemahnya: al-'Aliy, hlm. 331. 
tidak seperti yang kalian pernah pelajari, karena mereka akan hidup untuk generasi zaman yang berlainan dengan generasi zaman kalian". ${ }^{22}$

\section{2) Pengorganisasian}

Pengorganisasian pembelajaran memberikan gambaran bahwa kegiatan belajar dan mengajar mempunyai arah dan penanggungjawab yang jelas. Artinya dilihat dari komponen yang terkait dengan pembelajaran pada institusi sekolah memberi gambaran bahwa jelas kedudukan kepala sekolah dalam memberikan fasilitas dan kelengkapan pembelajaran, dan kedudukan guru untuk menentukan dan mendesain pembelajaran dengan mengorganisasikan alokasi waktu, desain kurikulum, media dan kelengkapan pembelajaran. Kemudian jelas kedudukan siswa dalam mengikuti kegiatan belajar baik di kelas maupun belajar di rumah, di bawah koordinasi guru dan juga orang tua siswa.

Aspek-aspek pengorganisasian pembelajara meliputi: (a) menyediakan fasilitas, perlengkapan dan personel yang diperlukan untuk penyusunan kerangka yang efisien dalam melaksanakan rencanarencana melalui sebuah proses penetapan pelaksanaan pembelajaran yang diperlukan untuk menyelesaikannya; (b) pengelompokan komponen pembelajaran dalam struktur sekolah yang teratur; (c) membentuk struktur wewenang dan mekanisme koordinasi pembelajaran; $\quad$ (d) merumuskan dan menetapkan metode dan prosedur pembelajaran; dan $\quad$ (e) memilih, mengadakan latihan dan pendidikan dalam rangka pertumbuhan jabatan guru dilengkapi dengan sumber-sumber lain yang diperlukan.

Pengorganisasian pembelajaran ini memberi gambaran apakah seseorang guru mampu mengelola kelas dengan menggunakan teknik dan langkah tertentu seperti yang tertuang dalam perenanaan pengajaran yang dibuatnya sendiri, sehingga proses pmbelajaran berlangsung dengan suasana yang harmonis, edukatif, meaning full, berkualitas, dan mengarah pada pencapaian tujuan yang telah ditentukan. ${ }^{23}$

22Kaelani dan Diding Nurdin, Manajemen Pendidikan Islam: Kajian Kontemplatif Berdasarkan Pendekatan Interdisipliner, Filosofis, Paedagogis, Psikologis dan Sosial, (Cirebon: LSM PPMP, 2007), hlm. 5.

23Syaeful Sagala, Konsep dan Makna, hlm. 144. 
Pengorganisasian, dalam pandangan Islam bukan semata-mata merupakan wadah, akan tetapi lebih menekankan bagaimana pekerjaan dapat dikerjakan secara rapi, teratur dan sistematis. Hal ini sebagaimana diilustrasikan dalan al-Quran, ${ }^{24}$ sebagaimana firman Allah SWT:

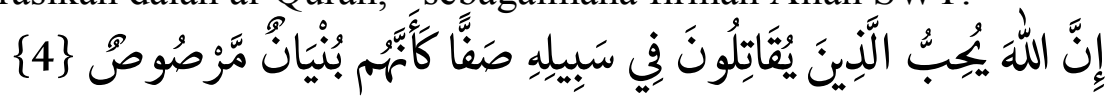

"Sesungguhnya Allah menyukai orang yang berperang dijalanNya dalam barisan yang teratur seakan-akan mereka seperti suatu bangunan yang tersusun kokoh". (QS. al-Shaff [61]: 4) $)^{25}$

Terkait dengan Pengorganisasian ini, Nabi Muhammad SAW bersabda:

$$
\text { إذَا وُسِدَ الْأَمْرَ غَيْر اَهْلِفِ فَنْتَظِرُ السَّاعَة (رواه البخارى) }
$$

"Apabila suatu urusan diserahkan bukan pada ahlinya, maka tunggulah saat kehancurannya" (HR. Bukhori). ${ }^{26}$

Sahabat 'Ali bin Abi Thalib RA pun pernah menyatakan:

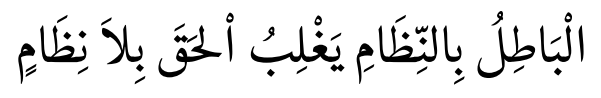

"Kebatilan yang terorganisir dapat mengalahkan kebenaran yang tidak terorganisir". ${ }^{27}$

\section{3) Penggerakan/Menggerakan (Actuating)}

Menurut G. R. Terry (1977), menggerakan (Actuating) berarti merangsang anggota-anggota kelompok untuk melaksanakan tugas-

24 M Munir dan Wahyu Ilaihi, Manajemen Dakwah, (Jakarta: Kencana, 2009), hlm. 98.

25 Departemen Agama RI, Al-Quran dan Terjemahnya: Al-'Aliy, hlm. 331.

26 U Saefullah, Manajemen, hlm. 128.

27 Muhammad Ruswandi dan Rama Adeyasa, Manajemen Mentoring, (Bandung: Syamil, 2007), hlm. 13. 
tugas dengan antusias dan kemampuan yang baik. Karena perencanaan dan pengorganisasian yang baik menjadi kurang berarti bila tidak diikuti dengan pelaksanaan kerja yang baik pula. Untuk itu maka dibutuhkan kerja keras, kerja cerdas dan kerjasama. Semua Sumber Daya Manusia (SDM) yang ada harus dioptimalkan untuk mencapai tujuan dan program pembelajaran.

Penggerakan dalam koteks pembelajaran dilakukan oleh pendidik dengan suasana yang edukatif agar siswa dapat melaksanakan tugas belajar dengan antusias, serta mengoptimalkan kemampuan belajarnya dengan baik dan penuh keikhlasan untuk semata meraih Ridha Allah SWT. Seperti tercantum dalam al-Quran:

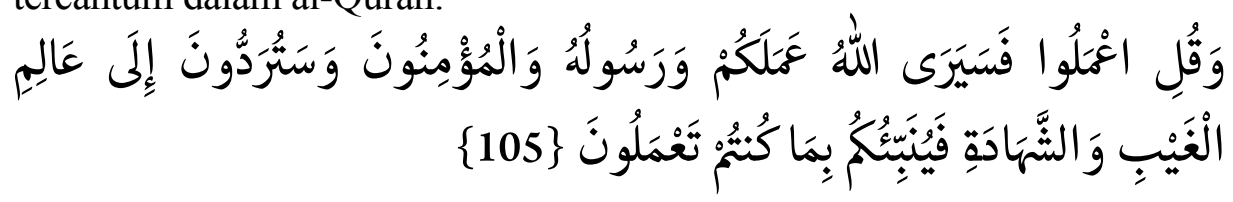

"Dan katakanlah: "Bekerjalah kamu, maka Allah dan RasulNya serta orang-orang mu'min akan melihat pekerjaanmu itu, dan kamu akan dikembalikan kepada (Allah) Yang Mengetahui akan yang ghaib dan yang nyata, lalu diberitakan-Nya kepada kamu apa yang telah kamu kerjakan.”. (QS. al-Taubah [9]: $105)^{28}$

Juga dalam ayat yang lain:

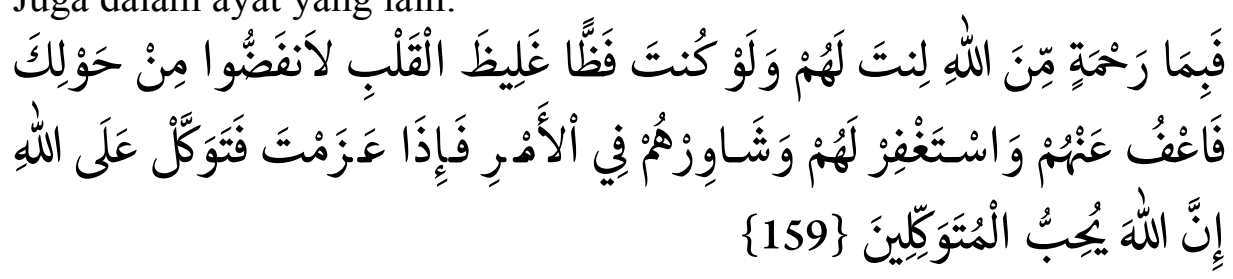

"Maka disebabkan rahmat dari Allah-lah kamu berlaku lemah lembut terhadap mereka. Sekiranya kamu bersikap keras lagi berhati kasar, tentulah mereka menjauhkan diri dari sekelilingmu. Karena itu ma'afkanlah mereka, mohonkanlah ampun bagi mereka, dan bermusyawaratlah dengan mereka dalam urusan itu . Kemudian apabila kamu telah membulatkan tekad, maka

28Departemen Agama RI, al-Quran dan Terjemahnya: al- 'Aliy, hlm. 162. 
bertawakkallah kepada Allah. Sesungguhnya Allah menyukai orang-orang yang bertawakkal kepada-Nya.”. (QS. Ali ‘Imron [3]: $159)^{29}$

\section{4) Pengawasan/Pengendalian}

Menurut Anthony, Dearden, dan Bedford (1984) bahwa pengawasan dimaksudkan untuk memastikan agar anggota organisasi melaksanakan apa yang dikehendaki dengan mengumpulkan, menganalisis dan mengevaluasi informasi serta memanfaatkannya untuk mengendalikan organisasi.

Guru melakukan pengawasan terhadap program yang ditentukanya apakah sudah dilaksanakan sesuai rencana yang telah ditetapkannya sendiri ataukah belum. Jika ada kekeliruan atau ada program yang tidak dapat diselesaikan maka segera dilakukan perbaikan dalam perencanaannya, sehingga tujuan yang sebelumnya ditentukan tetap secara optimal dapat dipenuhi.

Pengawasan dalam pembelajaran meliputi: (a) mengevaluasi kegiatan pembelajaran, dibanding dengan rencana; (b) melaporkan penyimpangan untuk tindakan koreksi dan merumuskan tindakan koreksi, menyusun standar-standar pembelajaran dan sasaran-sasaran; dan (c) menilai pekerjaan dan melakukan tindakan koreksi terhadap penyimpangan-peyimpangan baik institusional satuan pendidikan maupun proses pembelajaran.

Guru harus mengatur pikiranya yang kacau, ia harus dapat melihat dengan jelas apa-apa yang sedang ia usahakan untuk dikerjakan, dan mengutarakannya dengan cara yang paling logis dan teratur dengan landasan yang benar. $^{30}$ Dalam melakukan pengawasan/pegendalian harus disertakan unsur perbaikan yang berkesinambungan (continous improvement). ${ }^{3 l}$ Hal ini sebagaimana disinyalir dalam al-Quran:

29Ibid, hlm. 56.

30Syaeful Sagala, Konsep dan Makna Pembelajaran, hlm. 147-147.

31 M. Munir dan Wahyu Ilaihi, Manajemen Dakwah, hlm. 168. 


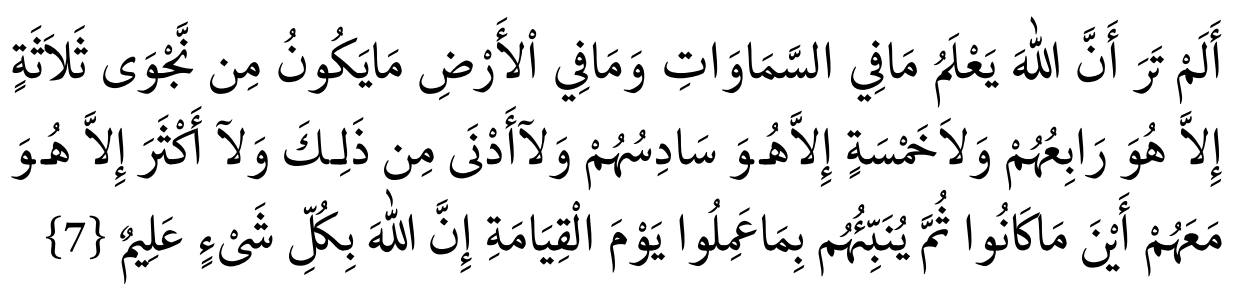

"Tidakkah kamu perhatikan, bahwa sesungguhnya Allah mengetahui apa yang ada di langit dan di bumi? Tiada pembicaraan rahasia antara tiga orang, melainkan Dia-lah keempatnya. Dan tiada (pembicaraan antara) lima orang, melainkan Dia-lah keenamnya. Dan tiada (pula) pembicaraan antara jumlah yang kurang dari itu atau lebih banyak, melainkan Dia berada bersama mereka di manapun mereka berada. Kemudian Dia akan memberitahukan kepada mereka pada hari kiamat apa yang telah mereka kerjakan. Sesungguhnya Allah Maha mengetahui segala sesuatu". (QS. al-Mujadilah [58]: 7) $)^{32}$

\section{Pembelajaran Agama Islam}

\section{Pengertian Pendidikan Agama Islam (PAI)}

Pada dasarnya pengertian pendidikan agama tidak dapat dipisahkan dangan pengertian pendidikan pada umumnya, sebab pendidikan agama merupakan bagian integral dari pendidikan secara umum. Didalam UUSPN No. 20 tahun 2003 dijelaskan bahwa:

"Pendidikan adalah usaha sadar dan terencana untuk mewujudkan suasana belajar dan proses pembelajaran agar peserta didik secara aktif mengembangkan potensi dirinya untuk memiliki kekuatan spiritual keagamaan, pengendalian diri, kepribadian, kecerdasan, akhlak mulia, serta ketrampilan yang diperlukan dirinya, masyarakat, bangsa dan negara". ${ }^{33}$

Menurut Ahmad Tafsir, pendidikan adalah usaha pengembangan seseorang agar terbentuk perkembangan yang maksimal

32 Departemen Agama RI, al-Quran dan Terjemahnya: al-'Aliy, hlm. 433.

33 Undang-undang Sistem Pendidikan Nasional No. 20 Thn 2003. Bab I, Pasal 1, Poin 1, (Bandung: Fokusmedia, 2010), hlm. 2. 
dan positif. Usaha tersebut dapat dilakukan dengan berbagai cara, diantaranya: dengan cara pengajaran, yaitu mengembangkan pengetahuan dan keterampila peserta didik, dengan memberikan contoh (teladan), mendidik dengan cara menbiasakan, memberikan pujian dan hadiah, dan dengan cara lain-lainnya. ${ }^{34}$

Menurut Pengertian pendidikan lebih diperluas cakupannya sebagai aktivitas dan fenomena. Pendidikan sebagai aktivitas berarti upaya secara sadar yang dirancang untuk membantu seseorang atau sekelompok orang dalam mengembangkan pandangan hidup, sikap hidup, dan keterampilan hidup, baik yang bersifat manual (petunjuk praktis) maupun mental dan sosial. Sedangkan pendidikan sebagai fenomena adalah peristiwa perjumpaan antara dua orang atau lebih yang dampaknya ialah berkembangnya suatu pandangan hidup, sikap hidup, atau keterampilan hidup pada salah satu atau beberapa pihak. ${ }^{35}$

Berikut merupakan pengertian pendidikan agama Islam menurut para ahli:

Menurut Ahmad Tafsir, Pendidikan Agama Islam (PAI) merupakan nama kegiatan dalam mendidikkan agama Islam. ${ }^{36}$ Karena "Islam" adalah nama agama, dan sering kita sebut "agama Islam", maka Pendidikan Agama Islam boleh juga disebut "Pendidikan Islam", ${ }^{37}$ yang berarti, bimbingan yang diberikan seseorang kepada seseorang agar ia berkembang secara maksimal sesuai dengan ajaran Islam. ${ }^{38}$

Zakiyah Daradjat berpendapat bahwa Pendidikan Agama Islam adalah suatu usaha untuk membina dan mengasuh peserta didik agar senantiasa dapat memahami ajaran Islam secara menyeluruh. Lalu menghayati tujuan, yang pada akhirnya dapat mengamalkan serta menjadikan Islam sebagai pandangan hidup.

34 Ahmad Tafsir, Ilmu Pendidikan dalam Persefektif Islam, (Bandung: Remaja Rosdakarya, 2010), hlm. 28.

35 Muhaimin, Paradigma Pendidikan Islam: Upaya Mengefektifkan Pendidikan Agma Islam di Sekolah, (Bandung: PT Remaja Rosdakarya, 2008), hlm. 37.

36 Ahmad Tafsir, Filsafat Pendidikan Islami: Integrasi Jasmani, Rohani, dan Kalbu Memanusiakan Manusia, (Bandung: Remaja Rosdakarya, 2006), hlm. 277.

$37 \quad$ Ibid, hlm. 276.

38 Ahmad Tafsir, Ilmu Pendidikan, hlm. 32. 
Tayar Yusuf berpendapat bahwa Pendidikan Agama Islam sebagai usaha sadar generasi tua untuk mengalihkan pengalaman, pengetahuan, kecakapan, dan ketrampilan kepada generasi muda agar kelak menjadi manusia bertaqwa kepada Allah SWT. ${ }^{39}$

Di dalam GBPP Pendidikan Agama Islam sekolah umum, menjelaskan bahwa pendidikan Agama Islam adalah usaha sadar untuk menyiapkan siswa dalam menyakini, memahami, menghayati, dan mengamalkan agama Islam melalui kegiatan bimbingan, pengajaran, dan latihan dengan memperhatikan tuntutan untuk menghormati orang lain dalam hubungan kerukunan antar umat beragama dalam masyarakat untuk mewujudkan persatuan nasional. Disimpulkan oleh Muhaimin, Pendidikan Agama Islam yakni suatu kegiatan bimbingan, pengajaran dan/atau latihan yang dilakukan secara berencana dan sadar atas tujuan yang hendak dicapai. ${ }^{40}$

Dari beberapa pengertian Pendidikan Agama Islam diatas, dapat ditarik kesimpulannya bahwa Pendidikan Agama Islam merupakan usaha sadar dan terencana yang dilakukan pendidik dalam rangka untuk mempersiapkan peserta didik untuk meyakini, memahami, dan mengamalkan ajaran Islam sebagai pandangan hidup melalui kegiatan bimbingan, pengajaran atau pelatihan yang telah ditentukan secara maksimal untuk mencapai tujuan yang telah ditetapkan.

\section{Pengertian Pembelajaran Agama Islam}

Ahmad Tafsir mengusulkan agar nama mata pelajaran "Pendidikan Agama Islam" diganti dengan mata pelajaran "Agama Islam”. Karena yang diajarkan yaitu Agama Islam, bukan Pendidikan Agama Islam. Sedangkan Pendidikan Agama Islam (PAI) merupakan nama kegiatan dalam mendidikkan agama Islam. ${ }^{41}$

Dalam PP No. 55 Tahun 2007, menyatakan bahwa:

"Pendidikan Agama adalah pendidikan yang memberikan pengetahuan dan membentuk sikap, keperibadian, dan

39 Abdul Majid dan Dian Andayani, Pendidikan Agama Islam Berbasis Kompetensi: Konsep dan Implementasi Kuriikulum 2004, (Bandung: Remaja Rosdakarya, 2005), hlm. 130.

$40 \quad$ Muhaimin, Paradigma, hlm. 76.

41 Ahmad Tafsir, Filsafat, hlm. 277-278. 
keterampilan peserta didik dalam mengamalkan ajaran agamanya, yang dilaksanakan sekurang-kurangnya melalui mata pelajaran/kuliah pada semua jalur, jenjang, dan jenis pendidikan". ${ }^{42}$

Memperhatikan PP No. 55 Tahun 2007 di atas maka nama agama akan di cantumkan setelah penulisan "mata pelajaran/mata kuliah pendidikan agama", seperti "Mata Pelajaran Pendidikan Agama Islam"/"Mata Kuliah Pendidikan Agama Kristen" dan mata pelajaran agama lainnya dalam semua perlengkapan pembelajaran, seperti buku teks pelajaran, jadwal mata pelajaran, buku rapot, dan lain-lain.

Maka secara umum "Pembelajaran Agama Islam" dapat disamaartikan dengan "Pembelajaran Mata Pelajaran Pendidikan Agama Islam" atau "Pembelajaran Pendidikan Agama Islam".

Pembelajaran adalah proses interaksi peserta didik dengan pendidik dan sumber belajar pada suatu lingkungan belajar. ${ }^{43}$ Pembelajaran merupakan upaya untuk membelajarkan siswa. Pembelajaran pendidikan agama Islam adalah suatu upaya membuat peserta didik dapat belajar, butuh belajar, terdorong belajar, mau belajar, dan tertarik untuk terus-menerus mempelajari agama Islam, baik untuk kepentingan mengetahui bagaimana cara beragama yang benar maupun mempelajari Islam sebagai pengetahuan. ${ }^{44}$ Dalam defenisi ini terkandung makna bahwa dalam pembelajaran tersebut ada kegiatan merencanakan, memilih, menetapkan dan mengembangkan metode/strategi yang optimal untuk mencapai hasil pembelajaran yang diinginkan dalam kondisi tertentu.

42 Peraturan Pemerintah No. 55 Tahun 2007 tentang Pendidikan Agama dan Pendidikan Keagamaan, Bab I, Pasal 1, poin 1. (Bandung: Fokusmedia, 2010), hlm. 146.

43 Undang-undang Republik Indonesia Nomor 20 Tahun 2003 tentang Sistem Pendidikan Nasional, Bab I, Pasal 1, Point 20, (Bandung: Fokusmedia, 2010), hlm. 4. 44 Muhaimin, Paradigma, hlm. 183-184. 


\section{Pengembangan Manajemen Pembelajaran Agama Islam}

Pembelajaran adalah proses interaksi peserta didik dengan pendidik dan sumber belajar pada suatu lingkungan belajar". ${ }^{45}$ Pembelajaran terkait dengan bagaimana (how to) membelajarkan siswa atau bagaimana membuat siswa dapat belajar dengan mudah dan terdorong oleh kemauannya sendiri untuk mempelajari apa (what to) yang teraktualisasikan dalam kurikulum sebagai kebutuhan (needs). Karena itu, pembelajaran berupaya menjabarkan nilai-nilai yang terkandung di dalam kurikulum dengan menganalisis tujuan pembelajaran dan karakteristik isi bidang studi pendidikan yang terkandung dalam kurikulum yang ideal/potensial. Selanjutnya, dilakukan kegiatan untuk memilih, menetapkan, dan mengembangkan, cara-cara atau strategi pembelajaran yang tepat untuk mencapai tujuan pembelajaran yang ditetapkan sesuai kondisi yang ada, agar kurikulum dapat diaktualisasikan dalam proses pembelajaran sehingga hasil belajar terwujud dalam diri peserta didik. ${ }^{46}$

Guru merupakan manajer pembelajaran agama Islam di sekolah, karena tugas dan tanggungjawab utama seorang guru/pengajar adalah mengelola pengajaran dengan lebih efektif, dinamis, efisien dan positif, yang ditandai dengan adanya kesadaran dan keterlibatan aktif antara guru dan murid. ${ }^{47}$ Di bawah ini merupakan komponen-komponen pengelolaan (manajemen) pembelajaran, dalam upaya untuk mengembangkan manajemen pembelajaran agama Islam:

a. Guru mampu menyusun rencana pembelajaran, dengan indikatornya yaitu guru mampu:

1) Mampu mendeskripsikan tujuan/kompetensi pembelajaran.

2) Mampu memilih/menentukan materi.

3) Mampu mengorganisir materi.

4) Mampu menentukan metode/strategi pembelajaran.

5) Mampu menentukan sumber belajar/media/alat peraga pembelajaran.

45 Undang-undang Republik Indonesia Nomor 20 Tahun 2003 tentang Sistem Pendidikan Nasional, Bab I, Pasal 1, Point 20, (Bandung: Fokusmedia, 2010), hlm. 4.

46 Muhaimin, Paradigma, hlm.145.

47 Ahmad Rohani, Pengelolaan, hlm.1. 
6) Mampu menyusun perangkat penilaian.

7) Mampu menentukan teknik penilaian.

8) Mampu mengalokasikan waktu.

b. Guru mampu melaksanakan interaksi belajar mengajar, dengan indikatornya yaitu guru mampu:

1) Mampu membuka pengajaran.

2) Mampu menyajikan materi.

3) Mampu menggunakan metode/media.

4) Mampu menggunakan alat peraga.

5) Mampu menggunakan bahasan yang komunikatif.

6) Mampu memotivasi siswa.

7) Mampu mengorganisasi kegiatan.

8) Mampu berinteraksi dengan siswa secara kominikatif.

9) Mampu menyimpulkan pembelajaran.

10) Mampu memberikan umpan balik.

11) Mampu melaksanakan penilaian.

12) Mampu menggunakan waktu.

c. Guru mampu melakukan penilaian atas prestasi belajar peserta didik, dengan indikatornya yaitu guru mampu:

1) Mampu memilih soal berdasarkan tingkat kesukaran.

2) Mampu memilih soal berdasarkan tingkat pembeda.

3) Mampu memperbaiki soal yang tidak valid.

4) Mampu memeriksa jawaban.

5) Mampu mampu mengklasifikasi hasil-hasil penelitian.

6) Mampu mengolah dan menganalisis hasil penilaian.

7) Mampu mengolah hasil penilaian.

8) Mampu membuat interpretasi kecendrungan hasil penilaian.

9) Mampu menentukan korelasi antara soal berdasarkan hasil penilaian.

10) Mampu mengidentifikasi tingkat variasi hasil penilaian.

11) Mampu menyimpulkan dari hasil penilaian secara jelas dan logis.

d. Guru mampu melaksanaan tindak lanjut hasil penilaian prestasi belajar peserta didik, dengan indikatornya yaitu guru mampu:

1) Menyusun program tindak lanjut hasil penilaian.

2) Mengklasifikasikan kemampuan siswa. 
3) Mengidentifikasi kebutuhan tindak lanjut hasil penilaian.

4) Melaksanakan tindak lanjut.

5) Mengevaluasi hasil tindak lanjut.

6) Menganalisis hasil evaluasi program tindak lanjut hasil penilaian. ${ }^{48}$

\section{Kesimpulan}

Sebagai sebuah profesi, guru dituntut memiliki empat kompetensi,yaitu: kompetensi pedagogik, kepribadian, sosial, dan profesional, yang dimaksud dengan kompetensi pedagogik adalah kemampuan mengelola pembelajaran peserta didik. Terkait dengan kemampuan mengelola pembelajaran peserta didik (kompetensi pedagogik) inilah guru berkepentingan untuk melakukan manajemen pembelajaran.

Dengan demikian dapat diidentifikasi empat fungsi umum yang merupakan ciri pekerjaan seorang guru sebagai manajer, yaitu: (1) Merencanakan, ini adalah pekerjaan seorang guru untuk menyusun tujuan belajar; (2) Mengorganisasikan, ini merupakan pekerjaan seorang guru untuk mengatur dan menghubungkan sumber-sumber belajar; sehingga dapat mewujudkan tujuan pembelajaran dengan cara yang paling efektif dan efisien; (3) Memimpin/Menggerakan, ini adalah pekerjaan seorang guru untuk memotivasi, mendorong dan menstimulasikan siswanya, sehingga mereka akan siap untuk mewujudkan tujuan pembelajaran; dan (4) Mengawasi, ini merupakan pekerjaan seorang guru untuk menentukan apakah fungsinya dalam mengorganisasikan dan memimpin telah berhasil dalam mewujudkan tujuan yang telah dirumuskan.

Adapun yang merupakan komponen-komponen pengelolaan (manajemen) pembelajaran, dalam upaya untuk mengembangkan manajemen pembelajaran agama Islam, yaitu: (1) Guru mampu menyusun rencana pembelajaran; (2) Guru mampu melaksanakan interaksi belajar mengajar; (3) Guru mampu melakukan penilaian atas prestasi belajar peserta didik; dan (4) Guru mampu melaksanaan tindak lanjut hasil penilaian prestasi belajar peserta didik.

48 Abdul Majid, Perencanaan Pembelajaran: Mengembangkan Standar Kompetensi Guru, (Remaja Rosdakarya: Bandung, 2005), hlm. 7-8. 
Proses belajar mengajar dapat berlangsung dengan baik apabila seorang pendidik mampu mengelola pembelajaran dalam waktu yang tersedia dengan sebaik mungkin. Maka seorang guru harus mampu mengelola proses pembelajaran sehingga dapat menghasilkan peserta didik yang sesuai dengan tujuan pembelajaran pendidikan agama Islam.

\section{DAFTAR PUSTAKA}

Abdul Majid. 2005. Perencanaan Pembelajaran Mengembangkan Standar Kompetensi Guru. Remaja Rosdakarya: Bandung.

Abdul Majid dan Dian Andayani. 2004. Pendidikan Agama Islam Berbasis Kompetensi: Konsep dan Implementasi Kuriikulum 2004. Remaja Rosdakarya: Bandung.

Abdurrakhman Gintings. 2010. Esensi Praktis Belajar dan Pembelajaran. Humaniora: Bandung.

Abidin Ibnu Rusn. 1998. Pemikiran Al-Ghazali Tentang Pendidikan. Pustaka Pelajar: Yogyakarta.

Afifuddin dan Sobri Sutikno. 2008. Pengelolaan Pendidikan: Teori dan Praktek. Prospect: Bandung.

Ahmad Rohani. 2010. Pengelolaan Pengajaran: Sebuah Pengantar Menuju Guru Profesional. Jakarta: Rineka Cipta

Ahmad Tafsir. 2010. Ilmu Pendidikan dalam Perspektif Islam. Remaja Rosdakarya: Bandung. . 2006. Filsafat Pendidikan Islami: Integrasi Jasmani,

Rohani, dan Kalbu Memanusiakan Manusia. Remaja Rosdakarya: Bandung.

Azhar Arsyad. 2005. Media Pembelajaran. RajaGrafindo Persada: Jakarta.

Darwyan Syah, dkk. 2006. Perencanaan Sistem Pengajaran Pendidikan Agama Islam. Faza Media: Jakarta.

Departemen Agama RI. 2000. al-Quran dan Terjemahnya: al-'Aliy. Diponegoro: Bandung.

Hamdani. 2011. Strategi Belajar Mengajar. Pustaka Setia: Bandung.

Hasan Langgulung. 2003. Asas-Asas Pendidikan Islam. Pustaka alHusna: Jakarta. 
Hamzah B. Uno. 2011. Perencanaan Pembelajaran. Bumi Aksara: Jakarta.

http://ebsoft.web.id, Software KBBI v1.2.

Kaelani dan Diding Nurdin. 2007. Manajemen Pendidikan Islam :

Kajian Kontemplatif Berdasarkan Pendekatan Interdisipliner,

Filosofis, Paedagogis, Psikologis dan Sosial. LSM PPMP: Cirebon.

Mahmud. 2011. Metode Penelitian Pendidikan. Pustaka Setia: Bandung. Martinis Yamin dan Maisah. 2012. Manajemen Pembelajaran Kelas:

Strategi Meningkatkan Mutu Pembelajaran. Gaung Persada Press: Jakarta.

Muhaimin. 2008. Paradigma Pendidikan Islam: Upaya Mengefektifkan

Pendidikan Agma Islam di Sekolah. Remaja Rosdakarya:

Bandung.

. 2010. Pengembangan Kurikulum Agama Islam di Sekolah,

Madrasah dan Perguruan Tinggi. RajaGrafindo Persada: Jakarta.

Muhammad Ali. 2007. Guru dalam Proses Belajar Mengajar. Sinar Baru Algensindo: Bandung.

M. Munir dan Wahyu Ilaihi. 2009. Manajemen Dakwah. Kencana: Jakarta.

Muhammad Ruswandi dan Rama Adeyasa. 2007. Manajemen Mentoring. Syamil: Bandung.

Nana Syaodih Sukmadinata. 2005. Pengembangan Kurikulum: Teori dan Praktek. Remaja Rosdakarya: Bandung.

Nana Sudjana. 2009. Dasar-dasar Proses dalam Belajar Mengajar. Sinar Baru Algensindo: Bandung.

Nanang Fattah. 2011. Landasan Manajemen Pendidikan. Remaja Rosdakarya: Bandung.

Peraturan Pemerintah No. 55 Tahun 2007 tentang Pendidikan Agama dan Pendidikan Keagamaan. Fokus Media: Bandung.

Pius A. Tartanto dan M. Dahlan Al-Barry. 2001. Kamus Ilmiah Populer. Arloka : Surabaya.

Sudarwan Danim dan Yunan Danim. 2010. Adminstrasi dan Manajemen Kelas. Pustaka Setia: Bandung. 
Syaeful Sagala. 2012. Konsep dan Makna Pembelajaran. Al-Fabeta: Bandung.

Syuaeb Kurdi dan Abdul Aziz. 2005. Model Pembelajaran Efektif: PAI di SD dan MI. Pustaka Bani Quraisy: Bandung.

U. Saefulloh. 2012. Manajemen Pendidikan Islam. Pustaka Setia: Bandung.

Undang-undang Republik Indonesia Nomor 20 Tahun 2003 Tentang Sistem Pendidikan Nasional. Fokus Media: Bandung.

Tim BSNP. 2006. Panduan Penyusunan Kurikulum Tingkat Satuan

Pendidikan Jenjang Pendidikan Dasar dan Menengah. BNSP: Jakarta.

Tim Penyusun Kamus Pusat Bahasa. 2008. Kamus Bahasa Indonesia. Pusat Bahasa: Jakarta. (pdf.). 